\title{
Bioaccumulation of heavy metals and assessment of the human health risk of consumption of Clarias gariepinus and Parachanna obscura from the Owan River, Edo State, Nigeria
}

Ijeoma Patience Oboh*,

\section{Benjamin Chima Okpara}

Department of Animal and Environmental Biology,

Faculty of Life Sciences,

University of Benin., P.M.B. 1154, Benin City,

Edo State, Nigeria
Consumption of fish is a primary route of exposure to heavy metals that could be detrimental to human health due to the tendency of bioaccumulation and biomagnification along the food chain. The aim of this study was to evaluate the accumulation of heavy metals (Ni, Zn, Pb, Fe, and $\mathrm{Cr}$ ) in two commercially available fishes, Clarias gariepinus and Parachanna obscura, and to estimate the health risks they pose to humans through consumption. Twenty-four (24) fish samples (triplicates for each month for the two species) were collected between July and October 2017. Heavy metals were identified using the atomic absorption spectrophotometer and the health risk to consumers was evaluated using Estimated Daily Intake (EDI), the Target Hazard Quotient (THQ), and the Hazard Index (HI). The THQ for the individual metals in C. gariepinus and P. obscura occurred in the decreasing order of $\mathrm{Cr}>\mathrm{Pb}>\mathrm{Ni}$ and $\mathrm{Cr}>\mathrm{Pb}>\mathrm{Ni}>\mathrm{Fe}$ with risk values of $0.015,0.004$, and 0.001 , and $0.014,0.010,0.002$, and 0.001 , respectively. The hazard index for C. gariepinus and P. obscura were 0.021 and 0.027 , respectively. The values of the hazard index values of the two fish species were below the threshold value of 1 , an indication of no potential health risk to consumers of the fishes. However, with the occurrence of bioaccumulation of metals in the studied fishes, regular monitoring of the river is recommended.

Keywords: Heavy metals, bioaccumulation, health risks, hazard index

* Corresponding author. Email: obohij@yahoo.com 


\section{INTRODUCTION}

In recent years, fish species have attracted considerable interest in studies assessing biological and biochemical responses to environmental contaminants (Parente, Hauser-Davis, 2013). Fish are dominant species in virtually every aquatic ecosystem and play a fundamental role in the aquatic food-webs because of their function as carriers of energy from lower to higher trophic levels. The understanding of toxicant uptake, behaviour, and responses in fish is therefore of high ecological relevance (van der Oost et al., 2016).

Heavy metals are naturally occurring elements that have a high atomic weight and a density at least five times greater than that of water. Their multiple industrial, domestic, agricultural, medical, and technological applications have led to their wide distribution in the environment raising global public health concerns over their potential effects on human health and the environment (Scientific India, 2017). The concentration of heavy metals in an organism is the product of equilibrium between the concentration of the metal in an organism's environment and its rate of ingestion and excretion (Idodo-Umeh, 2002). Toxic effects occur when excretory, metabolic, storage, and detoxification mechanisms are no longer able to counter uptake (Kalay, Canli, 2000). Unlike organic contaminants that lose toxicity with time by biodegradation, heavy metals cannot be degraded and their concentration can be increased by bioaccumulation and biomagnification (Aksoy, 2008). Bioaccumulation is the net build-up of substances from water in an aquatic organism as a result of enhanced uptake and slow elimination of such substances (Bhattacharya et al., 2006). This is largely attributed to differences in the uptake and depuration period for various metals in different fish species (Tawari-Fufeyin, Ekaye, 2007). Studies have shown that accumulation of heavy metals in a tissue is mainly dependent on its concentration in water and its exposure period, although other environmental factors such as salinity, $\mathrm{pH}$, hardness, and temperature play significant roles in their accumulation (Quan et al., 2007; Jeffree et al., 2006; Singh et al., 2007).

This study was aimed at investigating the bioaccumulation of five heavy metals $(\mathrm{Ni}, \mathrm{Zn}$, $\mathrm{Pb}, \mathrm{Fe}$ and $\mathrm{Cr}$ ) in organs (the liver and muscle) of Clarias gariepinus and Parachanna obscura from the Owan River and at identifying the health risks they pose to humans through consumption.

\section{MATERIALS AND METHODS}

\section{Study area}

The study was conducted along a stretch of the Owan River in Ovia North-East Local Government Area, Edo State (Longitude $5^{\circ} 45^{\prime} \mathrm{E}$ and $5^{\circ} 48^{\prime} \mathrm{E}$ and Latitudes $6^{\circ} 48^{\prime} \mathrm{N}$ and $6^{\circ} 49^{\prime} \mathrm{N}$ ) (Fig. 1). The river takes its origin from Otuo in Owan East Local Government Area, runs through Okpokhumi, Sabongidda Ora, and empties into the River Osse, which transverses through Gelegele to Iziedema communities and finally empties into the Atlantic Ocean.

The Owan River is relatively calm and pristine with respect to the water quality, and supports a rich diversity of aquatic insects (Edegbene, Arimoro, 2012; Enuneku et al., 2013) and serves as a major source of water for domestic purpose within the communities along its banks (Omoigberale et al., 2014).

\section{Collection of water samples}

Eight (8) water samples were collected from two sampling points between the hours of 9:00 am and 12:00 noon from July to October 2017. Standard methods and procedures were followed during sample collection.

\section{Analysis of water samples}

In the laboratory, $\mathrm{pH}$, Total Dissolved Solids (TDS), Total Suspended Solids (TSS), Electrical Conductivity (EC), Turbidity, Dissolved Oxygen (DO), Biochemical Oxygen Demand (BOD5), chloride, sodium, potassium, magnesium, sulphate, nitrate, phosphate, lead, iron, zinc, nickel, and chromium were identified according to the procedures outlined in the Standard Methods for the Examination of 


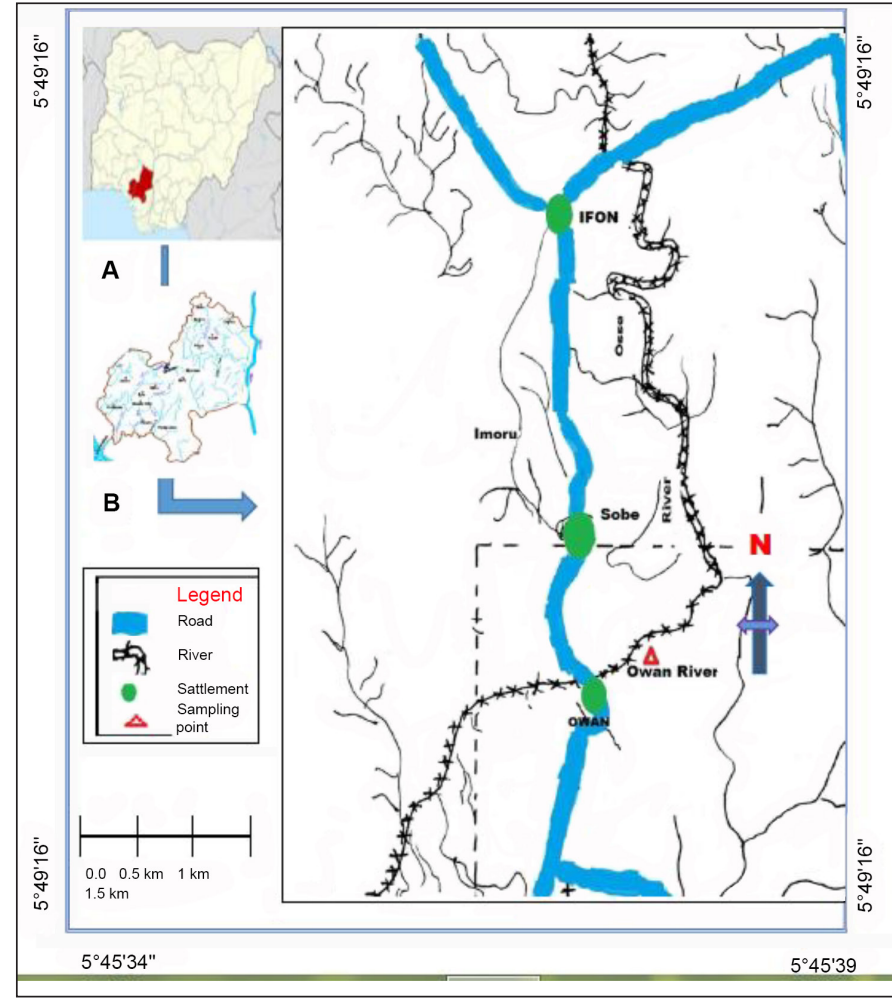

Figure. Map of the Owan River with the sampling point indicated. Inserts: (A) Nigeria, (B) Edo State
Water and Wastewater (APHA, 1998). The surface water temperature was taken in situ using a mercury-in-glass thermometer. Heavy metals - nickel $(\mathrm{Ni})$, zinc $\left(\mathrm{Zn}^{2+}\right)$, lead $\left(\mathrm{Pb}^{2+}\right)$, iron $\left(\mathrm{Fe}^{2+}\right)$, and chromium $\left(\mathrm{Cr}^{2+}\right)$ were identified after digestion of samples using an atomic absorption spectrophotometer (AAS).

\section{Digestion of fish samples}

In the laboratory, routine body measurements such as the total length and the standard length in centimetres $(\mathrm{cm})$ were taken to the nearest $0.1 \mathrm{~cm}$ using a measuring board. Fish weight in grams (g) were taken using a sensitive Mettler balance (Mettler P. E. 360) and the values recorded to the nearest $0.1 \mathrm{~g}$. Fish samples were then placed on a clean surface and $1 \mathrm{~g}$ wet weight of the fish tissue (muscle) along the lateral line was taken. The fish was dissected, the gut removed, and the liver extracted while still very fresh. After dissection, all the samples were labelled by species. The extracted liver and muscle portions were wrapped in foil paper, labelled, and oven dried at a temperature of $105^{\circ} \mathrm{C}$ for $1 \mathrm{~h}$. The dried samples were reduced to powder with a plastic mortar and pestle, sieved to obtain a uniform particle size, and preserved in well-labelled containers. The digestion procedure complied with the American Standard Methods for the Examination of Water and Waste (APHA, 1998).

\section{Bioaccumulation factor (BAF)}

The bioaccumulation factor (BAF) for heavy metals in fish is expressed below (Latif et al., 1982)

$$
\mathrm{BAF}=\frac{\text { Heavy metal concentration in fish }(\mathrm{mg} / \mathrm{kg})}{\text { Heavy metal concentration in water }(\mathrm{mg} / \mathrm{kg})} .
$$

\section{Assessment of the human health risk of fish consumption}

The models provided by the United States Environmental Protection Agency (USEPA, 2012) were used in determining the human health risk and they are the Estimated Daily Intake (EDI), Target Hazard Quotient (THQ), and Hazard Index (HI).

$$
\operatorname{EDI}(\mathrm{mg} / \mathrm{kg}-\mathrm{bw} / \text { day } / \text { week })=\frac{M I_{f} \times C M_{f}}{B W} .
$$

where $M I f=$ mass of fish ingested per day; $C M_{f}=$ concentration of metal in fish, and $B W=$ body weight $(60 \mathrm{~kg}$ for adult). In Nigeria, 
the per capita consumption of fish and shellfish for human food is $9.0 \mathrm{~kg}$, which is equivalent to 24.7 g per day. (USEPA, 2012; Duoye, Michael, 2015).

$$
\mathrm{THQ}=\frac{\mathrm{EF} \times \mathrm{ED} \times \mathrm{MI} \times \mathrm{CM}}{\mathrm{ORD} \times \mathrm{BW} \times \mathrm{AT}} \times 10^{-3}
$$

where THQ $=$ Target Hazard Quotient, EF $=$ Exposure Frequency (365 days/year); $\mathrm{ED}=$ Exposure Duration (52.62 years), which corresponded to average life expectancy of a Nigerian; (CIA, 2017); AT = average exposure time for non-carcinogens (365 days/year $\times \mathrm{ED}$ ). The Oral Reference Dose (ORD) is an estimate of daily exposure to human population (including the sensitive subgroup) that is likely to be without an appreciable risk of the deleterious effect during a lifetime. The Oral Reference Dose (ORD) $(\mathrm{mg} / \mathrm{kg} /$ day) used are $\mathrm{Ni}-2.0 \times 10-2$, $\mathrm{Zn}-3.0 \times 10-1, \mathrm{~Pb}-3.5 \times 10-3, \mathrm{Fe}-7.0 \times 10-$ 1 , and $\mathrm{Cr}-1.5 \times 10-3$ (USEPA, 2012).

The hazard index (HI) from the consumption of Clarias gariepinus and Parachanna obscura obtained from Owan River, Edo state, was calculated as the sum of THQs of all the metals in the fish samples and was expressed as follows;

$\mathrm{HI}=\mathrm{THQPb}+\mathrm{THQCr}+\mathrm{THQZn}+$ THQFe + THQNi

where $\mathrm{HI}=$ hazard index; $\mathrm{THQPb}=$ the Target Hazard Quotient for $\mathrm{Pb}$ intake; THQCu $=$ the Target Hazard Quotient for Cu intake, THQZn = the Target Hazard Quotient for Zn intake; THQFe = the Target Hazard Quotient for Fe intake, and THQNi = the Target Hazard Quotient for Ni intake.

\section{Data analysis}

The data obtained was analysed using the computer software SPSS (statistical package for social sciences) v.22. Basic statistical measurement of the central tendency and the t-test were used in the comparison between the heavy metal levels in the fish.

\section{RESULTS}

Table 1 shows the mean of physical and chemical parameters of the Owan River between July and October 2017. The mean levels of $\mathrm{Ni}$,

Table 1. Summary of physical and chemical parameters of the Owan River between July and October 2017

\begin{tabular}{ccc|cccc}
\hline Parameters & Mean \pm SD & Min & Max & NSDWQ 2007 & WHO 2011 \\
\hline Temperature ${ }^{\circ} \mathrm{C}$ & $35.75 \pm 0.96$ & 35.00 & 37.00 & & 27.00 \\
\hline Ph & $6.85 \pm 0.06$ & 6.80 & 6.90 & & $6.5-8.5$ \\
\hline E. C. $(\mu S / \mathrm{cm})$ & $42.50 \pm 33.04$ & 10.00 & 80.00 & N/A & N/A \\
\hline Turbidity(NTU) & $26.50 \pm 17.90$ & 11.42 & 26.50 & 5 & 5 \\
\hline TSS & $14.50 \pm 6.35$ & 9.00 & 20.00 & N/A & N/A \\
\hline TDS & $22.53 \pm 17.51$ & 5.30 & 31.8 & 500 & 1000 \\
\hline DO & $4.20 \pm 1.19$ & 2.80 & 5.60 & 7.5 & 5.0 \\
\hline BOD & $3.06 \pm 0.38$ & 2.60 & 3.50 & 0.05 & 0.05 \\
\hline Hardness & $21.50 \pm 4.43$ & 16.00 & 26.00 & N/A & 200 \\
\hline Alkanality & $27.00 \pm 17.32$ & 12.00 & 42.00 & N/A & N/A \\
\hline Sulphate & $5.50 \pm 3.32$ & 2.00 & 10.00 & 100 & 100 \\
\hline Nitrate & $2.03 \pm 0.55$ & 1.39 & 2.68 & 50 & 50 \\
\hline Phosphate & $0.29 \pm 0.08$ & 0.21 & 0.39 & 5 & 10 \\
\hline Chloride & $17.65 \pm 4.08$ & 14.12 & 21.18 & 250 & 400 \\
\hline Calcium & $6.42 \pm 3.00$ & 2.41 & 6.42 & & N/A \\
\hline Magnesium & $2.68 \pm 1.16$ & 1.46 & 3.90 & & 150 \\
\hline Nickel & $0.07 \pm 0.05$ & 0.00 & 0.13 & & 0.07 \\
\hline Zinc & $0.08 \pm 0.08$ & 0.00 & 0.21 & 3.0 & 3.0 \\
\hline Lead & $0.16 \pm 0.13$ & 0.00 & 0.23 & 0.01 & 0.01 \\
\hline Iron & $0.95 \pm 0.34$ & 0.72 & 1.34 & 0.3 & 0.3 \\
\hline Chromium & $1.36 \pm 0.46$ & 0.88 & 2.12 & & 0.05 \\
\hline
\end{tabular}


$\mathrm{Zn}, \mathrm{Pb}, \mathrm{Fe}$, and $\mathrm{Cr}$ in the liver and muscle of C. gariepinus were $0.25,0.57,0.02,2.18,0.48$, and $0.15,0.15,0.07,1.60$ and 0.62 , respectively, while $P$. obscura recorded mean concentrations of $0.34,0.72,0.28,5.67,0.66$ for the liver and $0.27,0.38,0.18,3.13$, and 0.57 for the muscle (Table 2). Significant differences $(p<0.05)$ were observed between the levels of $\mathrm{Zn}$ in the liver and muscle of C. gariepinus and between the lead concentration in the liver and muscle of $P$. obscura (Tables 2 and 3). The order of heavy metal accumulation observed in the liver and muscle of $C$. gariepinus of the Owan River was $\mathrm{Fe}>\mathrm{Zn}>\mathrm{Cr}>\mathrm{Ni}>\mathrm{Pb}$ and $\mathrm{Fe}>\mathrm{Cr}>\mathrm{Ni}>\mathrm{Zn}>\mathrm{Pb}$, respectively, while the same order of $\mathrm{Fe}>\mathrm{Cr}>\mathrm{Zn}>\mathrm{Ni}>\mathrm{Pb}$ was observed for both the liver and muscle of $P$. $o b$ - scura in the Owan River. Iron consistently had a higher concentration in both fishes studied.

\section{Bioaccumulation factor of fishes}

Table 4 shows bioaccumulation factors of heavy metals in C. gariepinus and P. obscura. All heavy metals analysed in both C. gariepinus and P. obsura revealed bioaccumulation factors greater than one (1) except for chromium and lead in C. gariepinus, and $\mathrm{Cr}$ in P. obscura.

\section{Health risk assessment of fishes}

The Estimated Daily Intake for Clarias gariepinus was in the order $\mathrm{Fe}>\mathrm{Cr}>\mathrm{Ni}=\mathrm{Zn}>\mathrm{Pb}$, while the THQ was $\mathrm{Cr}>\mathrm{Pb}>\mathrm{Ni}>\mathrm{Fe}=\mathrm{Zn}$ with risk values of $0.015,0.004,0.001,0.000$ and 0.000 , respectively (Tables 5 and 6). The hazard index

Table 2. Comparison of heavy metal concentrations in the liver and muscle of Clarias gariepinus

\begin{tabular}{c|cccccccc}
\hline $\boldsymbol{n}=4$ & \multicolumn{6}{c}{ Organs } & $p$-value & Standards \\
\hline $\begin{array}{c}\text { Heavy } \\
\text { metals }\end{array}$ & Mean \pm SD & Min & Max & Mean \pm SD & Min & Max & \\
\hline $\mathrm{Ni}$ & $0.25 \pm 0.10$ & 0.11 & 0.34 & $0.15 \pm 0.07$ & 0.08 & 0.25 & $p>0.05$ & $0.5(\mathrm{WHO}, 2003)$ \\
\hline $\mathrm{Zn}$ & $0.57 \pm 0.21$ & 0.32 & 0.83 & $0.15 \pm 0.05$ & 0.09 & 0.21 & $p<0.05^{\star}$ & $30(\mathrm{FAO}, 1983)$ \\
\hline $\mathrm{Pb}$ & $0.02 \pm 0.03$ & 0.00 & 0.07 & $0.07 \pm 0.03$ & 0.03 & 0.10 & $p>0.05$ & $0.5(\mathrm{WHO}, 2003)$ \\
\hline $\mathrm{Fe}$ & $2.18 \pm 0.64$ & 1.76 & 3.12 & $1.60 \pm 0.49$ & 1.05 & 2.05 & $p>0.05$ & $0.5(\mathrm{WHO}, 2003)$ \\
\hline $\mathrm{Cr}$ & $0.48 \pm 0.24$ & 0.22 & 0.76 & $0.62 \pm 0.41$ & 0.07 & 1.02 & $p>0.05$ & $0.15(\mathrm{WHO}, 2003)$ \\
\hline
\end{tabular}

Table 3. Comparison of heavy metal concentrations in the liver and muscle of Parachanna obscura

\begin{tabular}{|c|c|c|c|c|c|c|c|c|}
\hline \multirow[t]{2}{*}{$n=4$} & \multicolumn{6}{|c|}{ Organs } & \multirow[t]{2}{*}{$p$-value } & \multirow[t]{2}{*}{ Standards } \\
\hline & & ver & & & scle & & & \\
\hline $\begin{array}{l}\text { Heavy } \\
\text { metals }\end{array}$ & Mean \pm SD & Min & Max & Mean \pm SD & Min & Max & & \\
\hline $\mathrm{Ni}$ & $0.34 \pm 0.21$ & 0.12 & 0.61 & $0.27 \pm 0.13$ & 0.12 & 0.43 & $p>0.05$ & 0.5 (WHO, 2003) \\
\hline $\mathrm{Zn}$ & $0.72 \pm 0.27$ & 0.36 & 1.01 & $0.38 \pm 0.12$ & 0.21 & 0.50 & $p>0.05$ & 30 (FAO, 1983) \\
\hline $\mathrm{Pb}$ & $0.28 \pm 0.17$ & 0.10 & 0.48 & $0.18 \pm 0.06$ & 0.10 & 0.25 & $p<0.05^{*}$ & $0.5(\mathrm{WHO}, 2003)$ \\
\hline $\mathrm{Fe}$ & $5.67 \pm 0.84$ & 4.54 & 6.53 & $3.13 \pm 0.66$ & 2.43 & 4.00 & $p>0.05$ & 0.5 (WHO, 2003) \\
\hline $\mathrm{Cr}$ & $0.66 \pm 0.48$ & 0.12 & 1.14 & $0.57 \pm 0.73$ & 0.02 & 1.64 & $p>0.05$ & $0.15(\mathrm{WHO}, 2003)$ \\
\hline
\end{tabular}

Table 4. Bioaccumulation factors of C. gariepinus and P. obscura from Owan River

\begin{tabular}{ccc}
\hline Heavy metal & Clarias gariepinus & Parachanna obscura \\
\hline Nickel & 2.75 & 4.25 \\
\hline Zinc & 4.61 & 7.08 \\
\hline Lead & 0.28 & 1.47 \\
\hline Iron & 1.99 & 4.64 \\
\hline Chromium & 0.40 & 0.45 \\
\hline
\end{tabular}


Table 5. Assessment of the health risk of consumption of Clarias gariepinus from the Owan River

\begin{tabular}{c|cccc}
\hline Heavy Metals & \multicolumn{2}{|c|}{ Risk Model } & \% Contribution of metal to HI \\
\hline & EDI & THQ & \\
\hline $\mathrm{Ni}$ & 0.06 & 0.001 & 4.76 \\
\hline $\mathrm{Zn}$ & 0.06 & 0.000 & 0.00 \\
\hline $\mathrm{Pb}$ & 0.03 & 0.004 & 19.05 \\
\hline $\mathrm{Fe}$ & 0.66 & 0.000 & 0.00 \\
\hline $\mathrm{Cr}$ & 0.25 & 0.015 & No Risk \\
\hline $\mathrm{HI}$ & & 0.021 &
\end{tabular}

Table 6. Assessment of the health risk of consumption of Parachanna obscura from the Owan River

\begin{tabular}{cccc}
\hline Heavy metals & \multicolumn{2}{c|}{ Risk model } & \% Contribution of metal to HI \\
\hline & EDI & THQ & 7.40 \\
\hline $\mathrm{Ni}$ & 0.11 & 0.002 & 0.00 \\
\hline $\mathrm{Zn}$ & 0.15 & 0.000 & 37.04 \\
\hline $\mathrm{Pb}$ & 0.08 & 0.010 & 3.70 \\
\hline $\mathrm{Fe}$ & 1.29 & 0.001 & 51.85 \\
\hline $\mathrm{Cr}$ & 0.24 & 0.014 & No Risk \\
\hline $\mathrm{HI}$ & & 0.027 &
\end{tabular}

was 0.021. For Parachanna obscura, the EDI was in the order: $\mathrm{Fe}>\mathrm{Cr}>\mathrm{Zn}>\mathrm{Ni}>\mathrm{Pb}$, while the Target Hazard Quotient in the descending order was $\mathrm{Cr}>\mathrm{Pb}>\mathrm{Ni}>\mathrm{Fe}>\mathrm{Zn}$ with risk values of $0.014,0.010,0.002,0.001$ and 0.000 , respectively. The hazard index (HI) of heavy metals in this fish was 0.027 . In both fishes, chromium had the highest percentage contribution to the HI.

\section{DISCUSSION}

Bioaccumulation of metals in fish is considered an index of metal pollution in the aquatic bodies that can be a useful tool to study the biological role of metals present at higher concentrations in fish (Tawari-Fufeyin, Ekaye, 2007; Osman, Kloas, 2010).

Heavy metal concentrations were observed to be higher in fish than in water, which was indicative of bioaccumulation. Fish has the ability to concentrate heavy metals in their tissues to the concentration levels which comprise of several orders of magnitude higher than those in water (Oguzie, 2003). The difference in the levels of accumulation in different organs of a fish can be attributed to the differences in the physiologi- cal role of each organ. Other factors such as regulatory ability, behaviour and feeding habits may play a significant role in the differences of accumulation in these organs (Kehinde et al., 2016). Also, the chemical nature of the metals, the ionic strength, and $\mathrm{pH}$ tend to be a master variable in the accumulation process (Eneji et al., 2011).

C. gariepinus and P. obscura were revealed to have accumulated heavy metals in their liver and muscle. The ranges of Ni levels (0.12$0.61 \mathrm{mg} / \mathrm{kg}$ ) in P. obscura are similar to the values recorded by Obasohan (2007) for P. obscura, however, this was lower than the $1.28 \mathrm{mg} / \mathrm{kg}$ reported for C. gariepinus (Adewumi et al., 2014). The mean concentration of zinc in the muscle of C. garipeinus $(0.15 \mathrm{mg} / \mathrm{kg})$ is similar to the mean recorded by Ayeloja et al. (2014) for C. gariepinus. In contrast, Adewumi et al. (2014) reported a higher mean concentration for C. gariepinus. Sublethal levels of zinc in C. gariepinus have been known to adversely affect hatchability, survival, and haematological parameters of the fish (Cardeihac et al., 1981; Kori-Siakpere, Ubogu, 2008).

Mean lead ranges of $0.02 \mathrm{mg} / \mathrm{kg}$ and $0.07 \mathrm{mg} / \mathrm{kg}$ were observed for the liver and 
muscle of C. gariepinus, while the levels in P. obscura were $0.28 \mathrm{mg} / \mathrm{kg}$ and $0.18 \mathrm{mg} / \mathrm{kg}$ for liver and muscle, respectively. Similar levels of accumulation were reported by Anim et al. (2011) for P. obscura and Ayeloja et al. (2014) for C. gariepinus; Obasohan (2007), on the contrary, reported higher values in $P$. obscura.

The total mean accumulation of iron $(1.89 \mathrm{mg} / \mathrm{kg}$ and $4.40 \mathrm{mg} / \mathrm{kg}$ ) in C. gariepinus and $P$. obscura were lower than values reported by Anim et al. (2011), but higher than the mean value for C. gariepinus by Edward et al. (2013). The dominance of iron over other metals observed in this study is consistent with findings of Oronsaye et al., 2010; Akan et al., 2012; Edward et al., 2013; Ekpo et al., 2013; Nsofor, Ikpeze, 2014, and Omoregie et al., 2016. This may be explained by the fact that iron being the most abundant metal in the environment could conceivably be bioaccumulated more than other trace metals (Oronsaye et al., 2010). It has been reported that iron occurs at high concentrations in Nigerian soils (Asaolu, Olaofe, 2004). Furthermore, iron is the major respiratory pigment in the blood and is thus present in abundance in the circulatory system (Oronsaye et al., 2010).

Chromium is an essential trace metal and the biologically usable form of $\mathrm{Cr}$ plays an essential role in glucose metabolism (Kehinde et al., 2016). Mean concentrations of $0.48 \mathrm{mg} / \mathrm{kg}$ (liver) and $0.62 \mathrm{mg} / \mathrm{kg}$ (muscle) for C. gariepinus, and $0.66 \mathrm{mg} / \mathrm{kg}$ (liver) and $0.57 \mathrm{mg} / \mathrm{kg}$ (muscle) for P. obscura have similarly been reported by Aghoghovwia et al. (2016) for the liver and muscle of P. obscura. Obasohan (2007) and Omoregie et al. (2016) reported higher $\mathrm{Cr}$ ranges for $P$. obscura and C. gariepinus.

The observed bioaccumulation factors in this study suggest that C. gariepinus and P. obscura are contaminated with these heavy metals. Bioaccumulation of metals in various organs of fish may cause structural lesions and functional disturbances (Jezierska, Witeska, 2006) thus affecting physiological functions in the fish and portending serious dangers to humans who consume these fishes.
The hazard index via the consumption of C. gariepinus and P. obscura were 0.021 and 0.027 , respectively. Since the HI is less than one (1), it can be inferred that the consumption of these fishes is unlikely to pose any health risks to consumers hence allaying fears of heavy metalinduced toxicities. Bearing in mind the tendency of bioaccumulation of heavy metals in fish and their non-degradability in human systems, it becomes imperative to continuously monitor heavy metal levels to ascertain the risks they pose to humans.

\section{ACKNOWLEDGEMENTS}

The authors are grateful to the Benin Owena River Basin Laboratory and Department of Chemistry laboratory for doctoral studies, University of Benin, for providing equipment and assistance in the analysis of the samples.

Received 23 November 2018

Accepted 25 July 2019

\section{References}

1. Adewumi DF, Daniyan IA, Adeodu AO. Determination of heavy metals in water, fish and soil samples from Antau River in Keffi, Nasarawa State, Nigeria: a case study of Antau River in Keffi, Nasarawa North Central Nigeria. Int J Sci Res. 2014; 3(3): 2319-7064.

2. Aghoghovwia OA, Ohimain EI, Izah SC. Bioaccumulation of heavy metals in different tissues of some commercially important fish species from Warri River, Niger Delta, Nigeria. Biotec Res J. 2016; 2(1): 25-32.

3. Akan JC, Salwa M, Yikala BS, Chellube ZM. Study on the distribution of heavy metals in different tissues of fishes from River Benue in Vinikilang, Adamawa State, Nigeria. Br J App Sci Technol. 2012; 2(4): 311-33.

4. Aksoy A. Chicory (Cichorium intybus L.): a possible biomonitor of metal pollution. Pak J Bot. 2008; 40(2): 791-7. 
5. American Public Health Association. Standard methods for the examination of water and waste water. 20th ed. Washington: American Public Health Association; 1998. 1134 p.

6. Anim AK, Ahialey EK, Duodo GO, Ackah M, Bentil NO. Accumulation profile of heavy metals in fish samples from Nsawam, Along the Densu River, Ghana. Res J Environ Earth Sci. 2011; 3(1): 56-60.

7. Asaolu SS, Olaofe O. Bio-magnification factors of some heavy and essential metal in sediments, fish and crayfish from Ondo State Coastal Region. Biol Sci Res. 2004; 6: 13-39.

8. Ayeloja AA, George FOA, Shorinmade AY, Jimoh WA, Afolabi QO, Olawepo KD. Heavy metal concentrations in selected fish species from Eleyele reservoir, Ibadan, Oyo State, South Western Nigeria. Afr J Environ Sci Technol. 2014; 8(7): 422-7.

9. Bhattacharya AK, Mandal SN, Das SK. Bioaccumulation of chromium and cadmium in commercially edible fishes of gangetic West Bengal. Trends Applied Sci Res. 2006; 1: 511-7.

10. Cardeihac PT, Simpson CF, White F, Thompson TNP, Carr WE. Evidence of metal poisoning in acute death of large red dram Scanops ocellata. Bull Environ Physiol Toxic1. 981; 27: 639-44.

11. Central Intelligence Agency (CIA). The World Fact Book. 2017 [Available at: https://www.cia. gov/library/publications/the-world-factbook/ rankorder/2102rank.html].

12. Douye PM, Michael HJ. Assessment of noncarcinogenic human health risk of some heavy metals in land snails commonly consumed in Bayelsa State, Nigeria. Res J Chem Sci. 2015; 5(10): 61-6.

13. Edward JB, Idowu EO, Oso JA, Ibidapo OR. Determination of heavy metal concentration in fish samples, sediment and water from Odo-Ayo River in Ado-Ekiti, Ekiti-State, Nigeria. IJEMA. 2013; 1(1): 27-33.

14. Ekpo FE, Agun N, Apkan UI. Influence of heavy metal concentrations in three common fish, sediment and water collected within quarry environment. Eur J Toxicol Sci. 2013; 201: 33.

15. Eneji IS, Sha'Ato R, Annune PA. Bioaccumulation of heavy metals in fish (Tilapia zilli and Clarias gariepinus) organs from River Benue, North-Central Nigeria. Pak J Anal Environ Chem. 2011; 12(1-2): 25-31.

16. Enuneku A, Ezemonye LI, Adibeli F. Heavy metal concentrations in surface water and bioaccumulation in fish (Clariasgariepinus) of River Owan, Edo state, Nigeria. EIJST. 2013; 2(7): 31-9.

17. Idodo-Umeh G. Pollution assessments of Olomoro water bodies using physical, chemical and biological indices [doctoral dissertation]. Nigeria: University of Benin; 2002. 485 p.

18. Jeffree RA, Warnau M, Oberhansli F, Teyssie JL. Bioaccumulation of heavy metals and radionuclides from seawater by encased embryos of the spotted dogfish Scyliorhinus canicula. Mar Pollut Bull. 2006; 52(10): 1278-86.

19. Jezierska B, Witeska M. The metal uptake and accumulation in fish living in polluted waters. In: Twardowska I, Allen HE, Häggblom MM, Stefaniak S, editors. Soil and water pollution monitoring, protection and remediation. Springer: 2006; 107-14.

20. Kalay M, Canli M. Elimination of essential $(\mathrm{Cu}, \mathrm{Zn})$ and non-essential $(\mathrm{Cd}, \mathrm{Pb})$ metals from tissues of a freshwater fish Tilapia zilli. Turk J Zool. 2000; 24: 429-36.

21. Kehinde OH, Ajibola IO, Isaac S, Segun OO. Determination of heavy metal genotoxicity and their accumulation pattern in different fish organs of selected fish species collected from the Asa River, Ilorin, Kwara State, Nigeria. J Appl Sci Environ Manage. 2016; 20(3): 735-45.

22. Kori-Siapere O, Ubogu EO. Sublethal haematological effects of zinc on the freshwater fish, Heteroclarias sp. (Osteichthyes: Clariidae). Afr J Biotechnol. 2008; 7(12): 2068-73.

23. Latif A, Khalaf AN, Khallol BY. Bioaccumulation of $\mathrm{Cu}, \mathrm{Cd}, \mathrm{Pb}$ and $\mathrm{Zn}$ in two cyprinid fishes of Iraq. J Fish Bio. 1982; 13(2): 45-54. 
24. Nsofor CI, Ikpeze OO. Potential health hazards of consuming Clarias gariepinus fish contaminated with heavy metals of River Niger. GJBAHS. 2014; 3(2): 69-74.

25. Obasohan EE. Heavy metals concentrations in the offal, gill, muscle and liver of a freshwater mud fish Parachanao bscura from Ogba River, Benin City, Nigeria. Afr J Biotechnol. 2007; 6(22): 2620-7.

26. Oguzie FA. Heavy metals in fish, water and effluents of lower, Ikpoba River in Benin City, Nigeria. Pak J Sci Ind Res. 2003; 46(3): 156-60.

27. Omoigberale MO, Oboh IP, Erhunmwunse NO, Ezenwa IM, Omoruyi SO. An assessment of the trace metal contents of Owan River, Edo State, Nigeria. EIJST. 2014; 3(5): 88-98.

28. Omoregie PI, Imoobe TOT, Izegaegbe JI, Oluowo EF. Assessment of some heavy metals and total hydrocarbons in Clarias gariepinus fish of Osse River, Edo State. IOSR-JESTFT. 2016; 10(9): 144-51.

29. Oronsaye JAO, Wangboje OM, Oguzie FA. Trace metals in some benthic fishes of the Ikpoba river dam, Benin City, Nigeria. Afr J Biotechnol. 2010; 9(51): 8860-4.

30. Osman AGM, Kloas W. Water quality and heavy metal monitoring in water, sediments, and tissues of the African catfish Clarias gariepinus (Burchell, 1822) from the River Nile, Egypt. J Environ Protect. 2010; 1: 389-400.

31. Van der Oost R, Porter-Visa C, van der Brink NW. Biomarkers in environmental assessment. In: den Besten PJ. Munawar M, editors. Ecotoxicological testing of marine and freshwater animals. New York: CRC Press; 2016. p. 87-152.
32. Parente TEM, Hauser-Davis RA. The use of fish biomarkers in the evaluation of water pollution. In: Pollution and fish health in Tropical Ecosystems. 2013.

33. Quan WM, Han JD, Shen AL, Ping XY, Qian PL, Li CJ, Shi LY, Chen YQ. Uptake and distribution of N, P and heavy metals in three dominant salt marsh macrophytes from Yangtze River estuary, China. Mar Environ Res. 2007; 64(1): 21-37.

34. Scientific India. Toxic elements (Heavy Metals) in our food and their detoxification. 2017 [Available at: http://www.scind.org/902/ Health/toxic-elements-heavy-metals-in-ourfood-and-their-detoxification.html].

35. Singh RK, Chavan SL, Sapkale PH. Heavy metal concentrations in water, sediments and body tissues of red worm (Tubifex spp.) collected from natural habitats in Mumbai, India. Environ Monit Assess. 2007; 129(1-3): 471-81.

36. Tawari-Fufeyin P, Ekaye SA. Fish species diversity as indicator of pollution in Ikpoba river, Benin City, Nigeria. Rev Fish Biol Fisheries. 2007; 17: 21-30.

37. United States Environmental Protection Agency (USEPA). Risk assessment guidance for superfund: Vol III part A. Process for conducting probabilistic risk assessment EPA, 540-R-02-002 OSWER 9285745PB2002 963302. USEPA, Human Health Risk Assessment. 2012 [Available at: https://www.epa. gov/risk/risk-assessment-guidance-superfund-rags-volume-iii-part]. 
Ijeoma Patience Oboh, Benjamin Chima Okpara

SUNKIŲJŲ METALŲ BIOAKUMULIACIJA IR

CLARIAS GARIEPINUS BEI PARACHANNA

OBSCURA IŠ OWANO UPĖS (EDO VALSTIJA, NIGERIJA) VARTOJIMO RIZIKOS SVEIKATAI IVERTINIMAS

Santrauka

Žuvies vartojimas yra vienas pagrindinių sunkiųjų metalų patekimo i̇ organizmą būdų, galinčių pakenkti žmonių sveikatai dèl žuvyse vykstančios sunkiụjų metalų bioakumuliacijos ir biomagnetinès tendecijos maisto grandineje. Šio tyrimo tikslas buvo ịvertinti sunkiųjų metalų $(\mathrm{Ni}, \mathrm{Zn}, \mathrm{Pb}, \mathrm{Fe}$ ir Cr) kaupimąsi dviejose komercinèse žuvų rūšyse Clarias gariepinus ir Parachanna obscura bei ịvertinti jų vartojimo riziką sveikatai. Dvidešimt keturi žuvų mėginiai (po tris kiekvienos rūšies egzempliorius kiekvieną mènesị) buvo surinkti $2017 \mathrm{~m}$. liepos ir spalio mėnesiais. Sunkieji metalai buvo nustatyti atominès absorbcijos spektrofotometru, o rizika vartotojams ịvertinta apskaičiavus suvartojimą per parą (EDI) ir nustačius tikslinị pavojaus (THQ) ir pavojaus indeksus (HI). Nustatytas bendras atskiru metalų, esančiu C. gariepinus ir P. obscura, kiekis mažejančia tvarka $\mathrm{Cr}>\mathrm{Pb}>\mathrm{Ni}$ ir $\mathrm{Cr}>\mathrm{Pb}>\mathrm{Ni}>\mathrm{Fe}$, kai rizikos vertes buvo $0,015,0,004$ ir 0,001 bei 0,014, 0,010, 0,002 ir 0,001 atitinkamai. C. gariepinus pavojaus indeksas 0,021, P. obscura - 0,027. Abiejų žuvų rūšių pavojaus indekso vertès buvo mažesnès už ribinę $(p<1)$, todèl šių žuvų rūšiu vartojimas nèra pavojingas žmonių sveikatai. Kadangi tiriamose žuvyse vyksta sunkiųjų metalų bioakumuliacija, rekomenduojama reguliariai tikrinti upių užterštumą.

Raktažodžiai: sunkieji metalai, bioakumuliacija, rizika sveikatai, pavojingumo indeksas 